Article

\title{
Problem-Based Learning in University Studies on Renewable Energies: Case of a Laboratory Windpump
}

\author{
Alain Ulazia ${ }^{1, *}$ and Gabriel Ibarra-Berastegi ${ }^{2,3}$ \\ 1 Department of NE and Fluid Mechanics, University of the Basque Country (UPV/EHU), Otaola 29, \\ 20600 Eibar, Spain \\ 2 Department of NE and Fluid Mechanics, University of the Basque Country (UPV/EHU), Alda, \\ Urkijo, 48013 Bilbao, Spain; gabriel.ibarra@ehu.es \\ 3 Plentzia Itsas Estazioa, PIE, University of the Basque Country (UPV/EHU), 48620 Plentzia, Spain \\ * Correspondence: alain.ulazia@ehu.eus
}

Received: 12 February 2020; Accepted: 20 March 2020; Published: 23 March 2020

check for updates

\begin{abstract}
In the last eight years, the new faculty of Engineering in Renewable Energies at the University of the Basque Country in Eibar has developed several sustainability goals related to clean energy and climate change, but also in educative terms related to co-operative learning, motivation, and reflective thinking. The case of the laboratory-windpump challenge is paradigmatic in this sense, since it constitutes successful problem-based learning for the students in terms of the activation of heuristic tools (analogies or diagrams), critical discussions combining complex ideas about aerodynamics, mechanics and hydraulics, and a good group atmosphere. The conclusions of this work are supported by qualitative and quantitative results within a theoretical background based on the logic of discovery and its corresponding constructive-learning strategy, rather than on the logic of justification with given and well-known aprioristic assumptions.
\end{abstract}

Keywords: fluid mechanics; renewable energy; learn to learn; windpump; reflective thinking; higher education

\section{Introduction}

The pioneering faculty of Engineering in Renewable Energies in the University of Basque Country (Engineering School of Gipuzkoa at Eibar, [1]) is a challenging educational project that is tied in with the global sustainability agenda due to the importance of renewable energies in clean-energy production and in the fight against climate change [2].

The new grade started eight years ago with 70 students, and it has maintained these registration figures. After basic typical subjects in engineering, the students specialized in several renewable technologies in the third and fourth years. Our contribution, from the field of fluid mechanics, was related to wind energy (third course) and ocean energy (fourth course). The teachers obtained excellent results in the students' surveys in items related to motivation and reflective thinking [3]. According to the class observations of the teachers, the students carried out very active work on the basis of self-learning and co-operative problem solving, having a clear notion of the heuristic advantages of problem-based learning [4-7].

As the new grade was gradually implemented, apart from the technical aspects related to the subject contents, the methodological evolution of the educational features received special attention and was carefully monitored during these years. Along with our methodological developments in the area of fluid mechanics, we extensively shared our experience in papers and conferences [8-12]. 
The learning case presented here is part of the laboratory practices of the wind-energy subject in the third course, which comprises $25 \%$ of the class hours and of the final mark. The students learned basic notions of aerodynamic forces (lift and drag force) in the second course within the subject of fluid mechanics. During the program on wind energy, they learned, among other sections on resource assessment and mechanics, about the aerodynamics of wind turbines [13]:

1. the Betz theorem;

2. the behavior of aerodynamic profiles using basic $2 \mathrm{D}$ computational fluid dynamics;

3. blade-element-momentum theory for three-bladed horizontal-axis wind turbines; and

4. a comparison between horizontal- and vertical-axis turbines.

The effective comparison between the more widely used horizontal-axis turbines vs vertical-axis turbines was illustrated in this practical learning activity. A small-scale windpump, constructed in the fluid-mechanics laboratory [14] using recycled elements, offered the possibility to design a complex group problem-solving activity contextualized in three fundamental sustainable goals:

1. the production of clean energy,

2. the supply of fresh water, and

3. the mitigation of climate change [15].

A windpump is a system that uses wind energy to pump water. This type of windmill was used from ancient times to obtain clean water from underground or to drain water for agricultural or building purposes [16,17]. Nowadays, in many isolated regions of Africa or India, windpumping is, along with solar photovoltaic (PV) systems, the only option to obtain drinking water from wells [18-20].

The combination of aerodynamics, mechanics, and hydraulics converts the working principle of a windpump into a complex problem that can be categorized in different parts. Understanding its behavior and the computation of its working speed need the co-operation of various heuristic tools such as analogies and diagrams in a logic of discovery without clear and established assumptions, rather than in a logic of justification with given and well-known assumptions [4,21-23]. This logic of discovery creates a highly motivated problem-based learning environment that allows a constructivist pedagogical approach, as is shown in the results [24].

In this theoretical context, the University of the Basque Country has a general educative program called ERAGIN that develops co-operative and dynamic learning using active methodologies, such as problem- or project-based learning [25], in which some of the authors have developed a full program for the subject of fluid mechanics. The university also has another program related to sustainability called CAMPUS BIZIA LAB, derived from Erasmus Project's University Educators for Sustainable Development, in which university teachers collaborate to achieve sustainability goals [26]. The authors have been active in these programs. As part of the results, the students created a spin-off on the integration of wind energy in buildings [27].

The structure of the paper is as follows. First, the materials (windpump and wind tunnel) and methodology to solve the problem are shown. We then explain the theoretical background and learning strategy. Then, results are shown with the solution found by a student group, the marks in the student surveys about the activity, and the qualitative opinions and observations in class. Next, we discuss how to relate the learning strategies and the theoretical background with the didactic results. Finally, a short conclusion summarizes the main aspects, and some future improvements are suggested.

\section{Materials and Methodology}

\subsection{Background within Wind Energy Applications}

Although the leading wind turbines are three-bladed horizotal axis wind turbines (HAWT) based on the lift force and designed for the production of multi-megawatt power, vertical axis 
wind turbines (VAWT) based mainly on the drag force are very important for small wind energy production [28]. This kind of small turbines can be used for electricity production or storage in isolated locations hybridising it with solar energy, and also for the integration of wind energy in buildings $[13,27,29]$.

However, one of the advantages of drag-force based wind turbines is that its tip-speed ratio (the ratio between the tip speed of the blade and the wind speed) should be low and this turbine is therefore a 'slow machine'. The tip-speed ratio of a typical HAWT is around seven ('fast turbine'), and a drag-force HAWT's tip-speed ratio is bellow one [13]. Thus, being its rotation speed very low, the corresponding torque in the axis is high and is suitable to generate strong mechanical forces needed in applications such as water pumping.

\subsection{Laboratory Windpump}

In 2014, the layout of a small-scale laboratory windpump was designed and constructed in the context of a final-grade work by two students. Since then, around 350 students carried out the windpump problem-solving activity within the laboratory practices of the subject of wind energy taught in the Faculty of Engineering in Renewable Energies [1]. The main sections in the program of the subject of wind energy are resource assessment (which is taught using the $R$ programming language [3]), wind-turbine aerodynamics and mechanics, and the design of wind farms. The windpump laboratory activity for the most part corresponds to aerodynamics, and it constitutes a great example to differentiate drag turbines and typical horizontal-axis lift turbines with three blades [13].

Its size and height are adequate to position it behind the wind tunnel of the laboratory in order to capture output wind flow (see Figure 1). Table 1 shows the main characteristics of the wind tunnel, its control panel, generator, and data-acquisition system in the School of Engineering of Gipuzkoa at Eibar (Laboratory of Fluid Mechanics [14]).

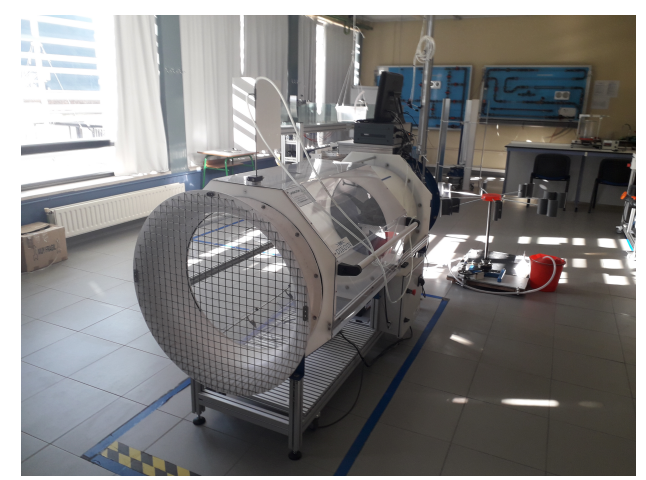

Figure 1. Windpump behind wind tunnel in fluid-mechanics laboratory at Engineering School of Gipuzkoa (Eibar).

Table 1. Wind-tunnel characteristics.

\begin{tabular}{lc}
\hline Length; diameter & $2 \mathrm{~m} ; 630 \mathrm{~mm}$ \\
\hline Measuring system & Pitot tubes, ultrasonic anemometer, and air-pressure transducers \\
\hline Range of wind speed & $0-13 \mathrm{~m} / \mathrm{s}$ \\
\hline Materials & Aluminum structure and polycarbonate dome \\
\hline Control panel & Potentiometer for regulation of wind speed, rpm, and torque \\
\hline Generator & Maxon RE motor $65 \mathrm{~mm}$, graphite brushes, 250 Watt [30] \\
\hline Data acquisition & Variable resistor with measurement of voltage, intensity, and power \\
\hline
\end{tabular}


A vertical-axis drag turbine with eight arms and corresponding double semicylindrical profiles (PVC pipes cut in half) were connected with a dual-gear system recycled from a bicycle. A crankshaft turns the motion of the second gear to the linear motion of a hydraulic piston that pumps the water.

Figure 2 shows the entire system with the value of its main radius $R$, the drag profile, and the piston connected to the crankshaft. Table 2 presents the list of the most relevant parts, parameters, and their dimensions and aerodynamic values.
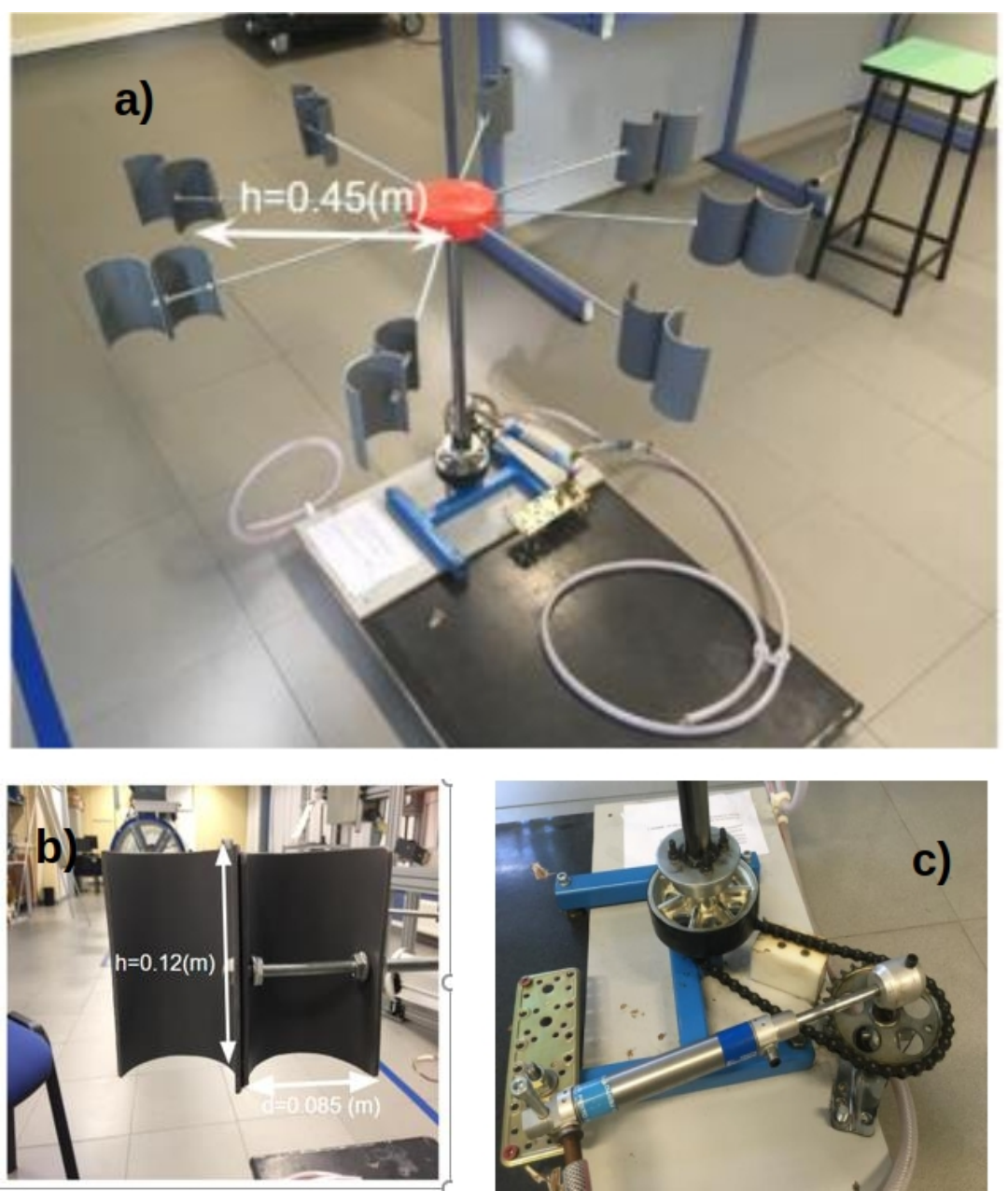

Figure 2. (a) Entire windpump view; (b) frontal view of drag profile; (c) hydraulic piston connected to the gear by a crankshaft.

Table 2. System parts, parameters, and their dimensions and aerodynamic values.

\begin{tabular}{clc}
\hline Parameter & Description & Measurement \\
\hline$A$ & Frontal area of drag profile & $8.25 \times 6.2 \mathrm{~cm}$ \\
$C_{D 1}$ & Frontal drag coefficient & 2.3 \\
$D$ & Piston diameter & $25 \mathrm{~mm}$ \\
$C_{D 2}$ & Reverse drag coefficient & 1.3 \\
$N$ & Multiplication factor in gear system & $28 / 16$ \\
$L$ & Piston stroke & $80 \mathrm{~mm}$ \\
$R$ & Windpump radius & $45 \mathrm{~cm}$ \\
$\eta$ & Efficiency of wind-hydraulic-energy transmission & $30 \%$ \\
\hline
\end{tabular}

The following video shows all the moving parts of the working windpump while the wind tunnel is generating air flow in the exit and the hydraulic piston is pumping water from the ground to a tank at $2 \mathrm{~m}$ height: https://www.youtube.com/watch?v=cVXv_ga18Eg. 


\subsection{Motivational Problem-Solving Activity}

A constructivist approach of a problem-solving challenge was proposed to the students in groups of three randomly selected persons. The groups were expected to build a step-by-step solution in a co-operative way. This challenge had a clearly positive influence in their motivation and attitude, and fostered co-operation between members [31]. Every year, more than 20 groups of the Faculty of Engineering in Renewable Energies participate in the challenge. For a given wind speed, pumping height, and pumping water volume, they have to guess the pumping time of the windpump in the public experiment carried out during the last week of the course.

These are the statements of the proposed problem and the first delivery work before the computation of the final experiment's pumping time:

1. Identify the elements that you think are relevant for pumping-time estimation. Write the list by naming them and accompanying them with a drawing.

2. Measure those elements, and redo the list again indicating each measurement.

3. Briefly write in your own words the operation principle of this pump by naming the previous elements.

4. Name external nonmechanical parameters that correspond to wind.

5. The goal is to hit in the final bet. We give the pumping height, the liters to pump, and the wind speed a week before. Taking into account all the above parameters, you have to write the equations that offer the solution.

(a) Construct and give the equation of the absorbed wind power by the turbine.

(b) Construct and give, taking into account the rotation speed of the turbine, the equation of the hydraulic power that generates the piston considering flow rate and pumping height.

(c) In the ideal case, these two powers (wind and hydraulic power) are equal, but according to our previous experiments, the energy that goes from the wind to the pump is reduced by $70 \%$. Assuming $U=10 \mathrm{~m} / \mathrm{s}$ and $h=2 \mathrm{~m}$, generate a graphical solution in $\mathrm{R}$ using the turbine rotation speed as a free variable.

6. Notes: As it is a drag machine, you should find the drag coefficients in the aerodynamic-data tables for the corresponding profiles. Be careful, as the drag profiles present important counterdrag behind the input wind flow. The wind tunnel acts only on one arm, while the others are outside the area of influence of the incoming air.

In this way, a maieutic method is used by the question and answers to elicit facts from the students supporting a teaching environment with strong critical thinking [32]. Verbal interaction with the teacher is minimal. In this way, ideas are assumed to be untainted from the lack of feedback from the teacher, but students do have internet access and access to classical handbooks, manuals, and lecture notes, with an important theoretical background on fluid mechanics and wind-turbine aerodynamics.

\subsection{Paradigmatic Solution}

The previous questions show a constructive path to solve the general problem that is based on a final motivational didactic group challenge. The solution is therefore deterministic and can be summarized as follows.

The eight arms of the drag turbine show positive (drag coefficient $C_{D 1}$ ) and negative drag (drag coefficient $C_{D 2}$ ) in the rotation of the turbine (see the final table of the abbreviations). The values of both drag coefficients could be obtained in the students' fluid-mechanics-data handbooks [33].

Given that there was one arm absorbing wind flux $U$ of the tunnel, and eight arms showing the reverse drag, total drag force is $[13,34]$

$$
F_{D}=\frac{1}{2} \rho A\left[C_{D 1} U_{r e l}^{2}-8 C_{D 2}\left(w_{1} R\right)^{2}\right]
$$


where $U_{r e l}$, relative wind speed given by the difference between $U$ and lineal motion of the arm $w_{1} R: U_{r e l}=U-w_{1} R ; \rho$, air density in the laboratory; $A$, frontal area of the aerodynamic surface; $R$, radius of the arms of the turbine; and $w_{1}$, angular velocity of drag turbine. Air density can be considered standard for first computation $\left(\rho_{0}=1.225 \mathrm{~kg} \mathrm{~m}^{-3}\right)$, but the students had to consider laboratory temperature $(T)$ and pressure $(p)$ in the moment of the experiment to obtain the real air density for $M=28.9$ (air molecular mass) and $R_{g}=8314 \mathrm{~J} / \mathrm{kmolK}$ (ideal gas constant):

$$
\rho=\frac{p M}{R_{g} T}
$$

In fact, this is an important aspect because air-density fluctuations due to temperature can produce strong changes of up to $20 \%$ in aerodynamic wind forces [35-38].

Thus, the generated power by the wind-turbine axis is torque $\left(F_{D} R\right)$ times $w_{1}$. This power $P_{e}$ is reduced by the total efficiency of the windpump $(\eta)$ to yield the final hydraulic power obtained in the piston pumping $\left(P_{h}\right)$ :

$$
\eta P_{e}=\eta F_{D} R w_{1}=P_{h}
$$

In the same way, the expression of $P_{h}$ is obtained as a function of the piston characteristics (diameter $D$, stroke $L$, oscillation frequency $w_{2}$ ), and pumping height $h$. Thus, hydraulic power considering piston water flow $Q$ is [19]

$$
P_{h}=\rho_{w} g Q h=\rho_{w} g \frac{w_{2}}{2 \pi} \frac{\pi}{4} D^{2} L h
$$

The key factor that relates $P_{e}$ with $P_{h}$ is transmission relation $N$ of the gears ( students had to count the number of teeth in both gears), which established proportionality relationship between angular velocities $N=\frac{w_{1}}{w_{2}}$.

This constructive procedure of the problem-solving activity implies only one unknown parameter $\left(w_{2}\right)$ in Equation (3), which could be solved graphically or numerically. Obviously, the final objective of the collaborative challenge, that is, pumping time $P_{t}$ of a volume of water $V$, is given by piston oscillation frequency $w_{2}$ that establishes the value of water flow $Q$ :

$$
P_{t}=\frac{V}{Q}=\frac{V}{\frac{w_{2}}{2 \pi} \frac{\pi}{4} D^{2} L}
$$

In this way, the apparently simple and specific question on pumping time involves a complex theoretical and technical solution process that could involve highly motivated initial brainstorming. Results in Section 3 confirmed this didactic hypothesis, and it is very important for activating the teaching strategy (see Figure 3).

\subsection{Theoretical Background}

This initial astonishment produced by the pumping-time question is considered by many philosophers as the origin of the logic of discovery in the framework of abduction, overcoming the axiomatic thinking of deduction and the probabilistic perspectives of induction $[23,39,40]$. This work based on the windpump challenge is therefore in the context of abductive thinking, as is discussed in Section 4, via the co-operation between heuristic tools. Abduction overcomes the typical discovery/justification dichotomy established by Popper [21,41], combining cycles of generation and evaluation in the creative process [4].

From a pedagogical perspective, constructivism and meaningful learning taken from Piaget or Vygotsky [24] is also present in the design of this learning strategy based on problem solving. Thus, the students are the protagonists since they participate in the construction of the solution from a heuristic and attitudinal perspective. 


\subsection{Execution Phases of Windpump-Problem-Based Learning Strategy}

In the previous sections, we generally described the execution phases. Figure 3 shows the workflow diagram of the execution phases for the windpump problem's learning strategy, which are well-known within strategies to promote competencies in sustainability [42].

\section{Phases of Teaching and Learning Strategies}

\begin{tabular}{|c|c|c|}
\hline $\begin{array}{c}\text { Execution Phases of the } \\
\text { Problem-Based Learning } \\
\text { Strategy }\end{array}$ & $\begin{array}{c}\text { Techniques Group } \\
\text { Activities }\end{array}$ & Learning Activities \\
\hline $\begin{array}{l}\text { Phase 1: Definition and Planning } \\
\text { 1.1 Problem Presentation } \\
\text { 1.2 Definition and delimitation in a } \\
\text { consensual way }\end{array}$ & $\begin{array}{l}\text { 1) Questionnaire of previous ideas } \\
\text { 2) Individual readings, analogies } \\
\text { 3) Brainstorm on the problem and } \\
\text { debate } \\
\text { 4) Presentation of proposals } \\
\text { 5) Work in groups for the definition } \\
\text { and delimitation of the problem } \\
\text { 6) Identify learning needs }\end{array}$ & $\begin{array}{l}\text { 1) Brainstorming } \\
\text { 2) New ideas characterization } \\
\text { 3) Group proposal preparation } \\
\text { 4) Criticism and reflection to } \\
\text { detect knowledge needs } \\
\text { 5) Development of the situational } \\
\text { diagnosis } \\
\text { 6) Systematic list of problem } \\
\text { analyses }\end{array}$ \\
\hline $\begin{array}{l}\text { Phase 2: Monitoring and Execution } \\
\text { 2.1. Process monitoring } \\
\text { 2.2. Presentation and justification } \\
\text { 2.3. Solutions choice } \\
\text { 2.4. Final report }\end{array}$ & $\begin{array}{l}\text { 1) Search and learn information } \\
\text { 2) Read and analyse of } \\
\text { documentation } \\
\text { 3) Information contrast } \\
\text { 4) Reports preparation } \\
\text { 5) Practical workshops } \\
\text { 6) Group discussions and feedback }\end{array}$ & $\begin{array}{l}\text { 1) Searching new information } \\
\text { 2) Analysis, organization and } \\
\text { synthesis of new information } \\
\text { 3) Establish the working plan } \\
\text { 4) Final report preparation } \\
\text { 5) Generation of possible solutions } \\
\text { 6) Group information debate }\end{array}$ \\
\hline $\begin{array}{l}\text { Phase } 3 \text { : Assessment } \\
\text { 3.1. Hetero-evaluation of } \\
\text { competencies } \\
\text { 3.2. Closure }\end{array}$ & $\begin{array}{l}\text { 1) Self-assessment activities } \\
\text { 2) Co-evaluation and aggregate } \\
\text { assessment } \\
\text { 3) Final report presentation }\end{array}$ & $\begin{array}{l}\text { 1) Criticism and reflection on the } \\
\text { problem solving process } \\
\text { 2) Writing and presentation of final } \\
\text { report and results } \\
\text { 3) Organization, synthesis and } \\
\text { solution proposals presentation } \\
\text { 4) Final report preparation }\end{array}$ \\
\hline
\end{tabular}

Figure 3. Phases of teaching and learning strategies of windpump problem-solving challenge.

The first phase of problem definition and planning is characterized by a questionnaire of previous ideas about drag machines, generation of new analogies based on well-known drag turbines, and group debate and brainstorming to present different proposals. This allows for reflective thinking and criticism, and the systematization and categorization of the general problem in different parts mainly related to mechanical parts involved in aerodynamic forces and hydraulic pumping.

In the second phase of monitoring and execution, students search for information about drag coefficients, hydraulic and aerodynamic torque and power, and other relevant data, and contrast the best relational ideas in the group discussions. In this way, they prepare the final report (see Section 3.1).

Finally, in the third phase of assessment, the final experiment to measure the pumping time produces heteroevaluation within the group challenge about the feelings and motivation of the group, the self-learning process, and the specific contents of the technical construction of the solution (see Section 3.2).

\section{Results}

\subsection{Student Solutions}

All the calculations of the students were carried out in the framework of the R programming language. $\mathrm{R}$ is an open-source language and environment for statistical computing that is widely used in the scientific community [43-45]. Using such a programming language represents an additional 
motivational element to the problem-solving challenge, since the broad online community involved in the construction and design of new tools and packages offers free information and help within a powerful motivational context of 'learn to learn'. The authors showed these didactic advantages of $\mathrm{R}$ in their previous publications about the teaching wind and ocean energy [3,12].

Figure 4 shows the code in R generated by a group of students and the graphical solution of oscillation frequency $w_{2}$ for a given pumping water volume $V$, wind speed $U$, and pumping height $h$ (see Equation (3)): $\eta P_{e}\left(w_{2}\right)=P_{h}\left(w_{2}\right)$.

The teachers had to develop various trial-and-error experiments with several aerodynamic configurations to optimize the windpump before it was used in the classroom. In these preliminary experiments, they computed the transmission efficiency of the aerodynamic power on the basis of drag forces into hydraulic power. These previous experiments showed that efficiency $\eta$ of the windpump system was around 30\% (loss of 70\%, as mentioned in Section 2.2), and this is available information to students for the initial proposed problem to guess pumping time.

a)

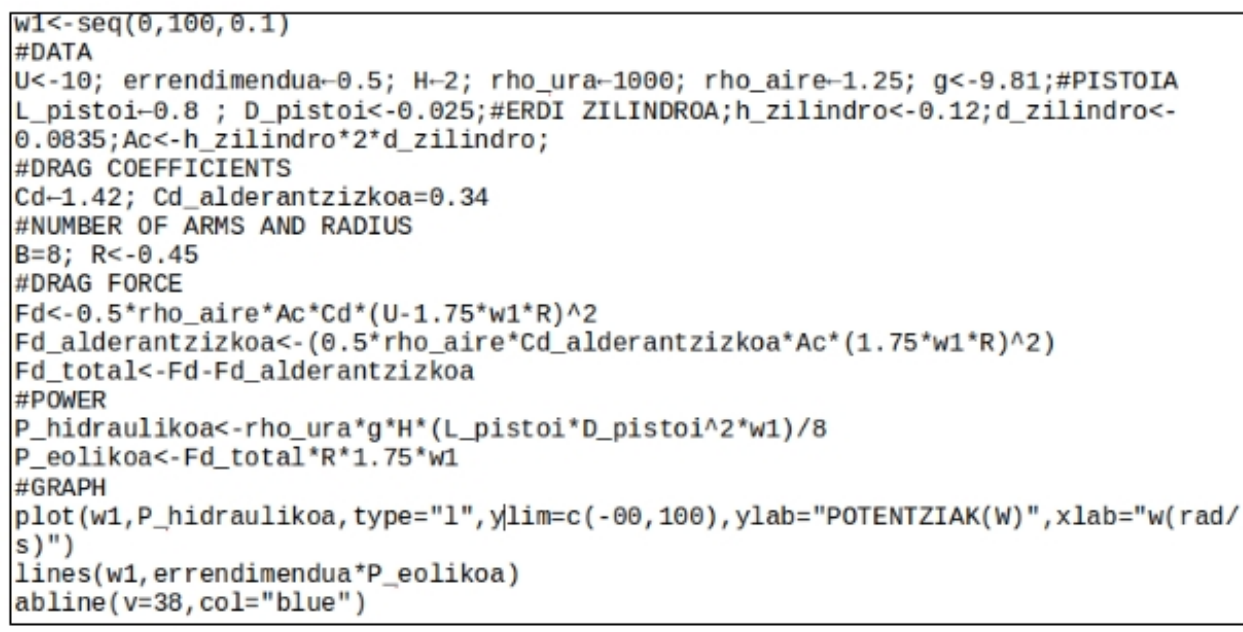

b)

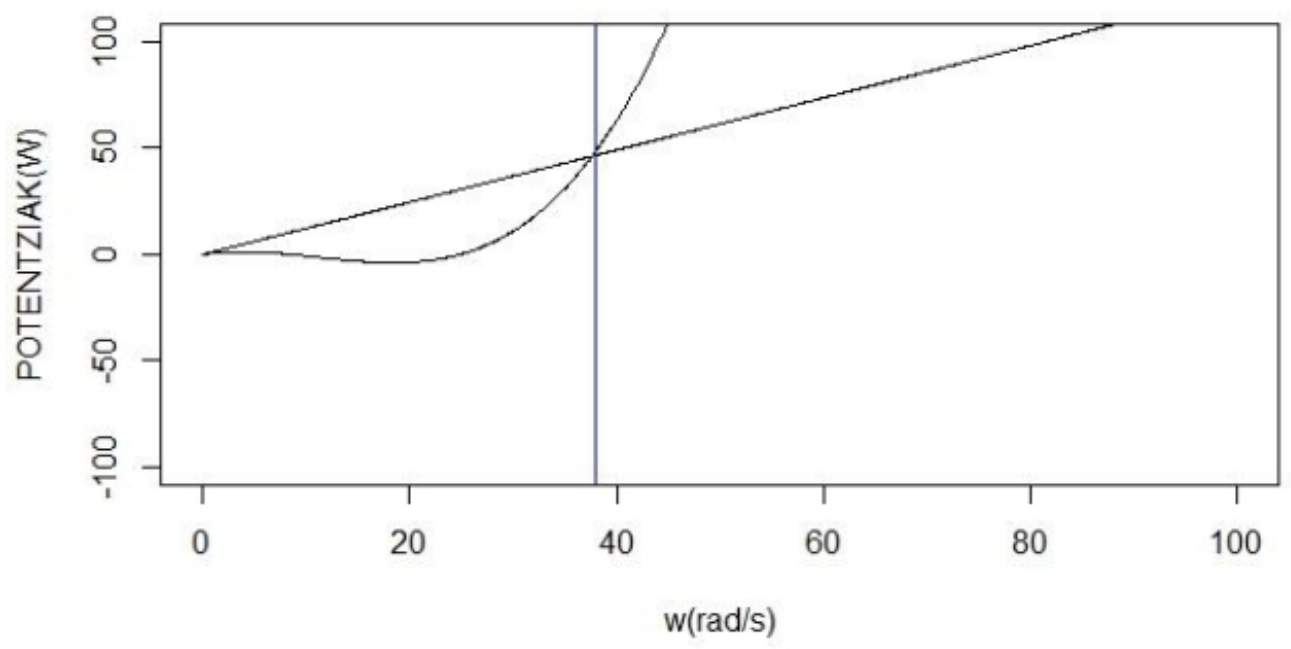

Figure 4. (a) R script of a group of students; (b) graphical solution presented by that group. 


\subsection{Student Evaluation}

\subsubsection{Quantitative Evaluation: Enquiries}

Table 3 shows the averages of the students' evaluation scores in the last five courses (2014-2019) for different didactic items involved in the practical activities in the laboratory, in which windpump activity plays an important role (30\% of laboratory hours). Only relevant didactic items are shown, and a comparative result is shown for the subject of wind energy (SS5) and for the general engineering high-school center's score (CS5), both with a score of 5 .

Table 3. Students' evaluation scores of practical laboratory activities for different didactic items.

\begin{tabular}{lcc}
\hline Evaluated Item & SS5 & CS5 \\
\hline Development of competencies & 4.3 & 3.8 \\
Practical resources & 4.1 & 3.5 \\
Motivation in learning process & 4.0 & 3.4 \\
Encouraging reflective thinking & 4.0 & 3.5 \\
Stimulating participation & 3.9 & 3.4 \\
Good group atmosphere & 4.1 & 3.6 \\
\hline Overall evaluation & 4.5 & 3.6 \\
\hline
\end{tabular}

The items related to motivation, participation, co-operative work, and practical resources are very good compared to the general averages of the engineering school, and use of reflective thinking is also higher than the average creating a better group work atmosphere. These items justify the final exceptional mark obtained in the overall evaluation of the subject of Wind Energy in its laboratory practices.

\subsubsection{Qualitative Evaluation: Student and Teacher Opinions}

After interviews with the student groups and observations during the resolution process of the windpump challenge, these qualitative facts were collected:

- The students were highly motivated during the initial brainstorming phase (see Figure 3), and they discussed and analyzed all aspects and elements of the problem within the group without interruptions. They were very focused on the problem.

- In these discussions, they combined several heuristic tools, such as diagrammatic thinking, analogical reasoning, and abstraction.

- They drew many diagrams and sketches to be able to think about the problem and to categorize its parts (see Figure 5).

- They tried to remember analogous problems related to different parts of the construction of the solution. For instance, they initially used the example in the section about drag machines in the referential book of Manwell et al. [13] (see Figure 6), in which a vertical-axis drag machine with plane blades, protected by a semicylinder, was analyzed.

- The combination of ideas via abstraction was first expressed algebraically and then computationally via the R language (see Figure 4). 


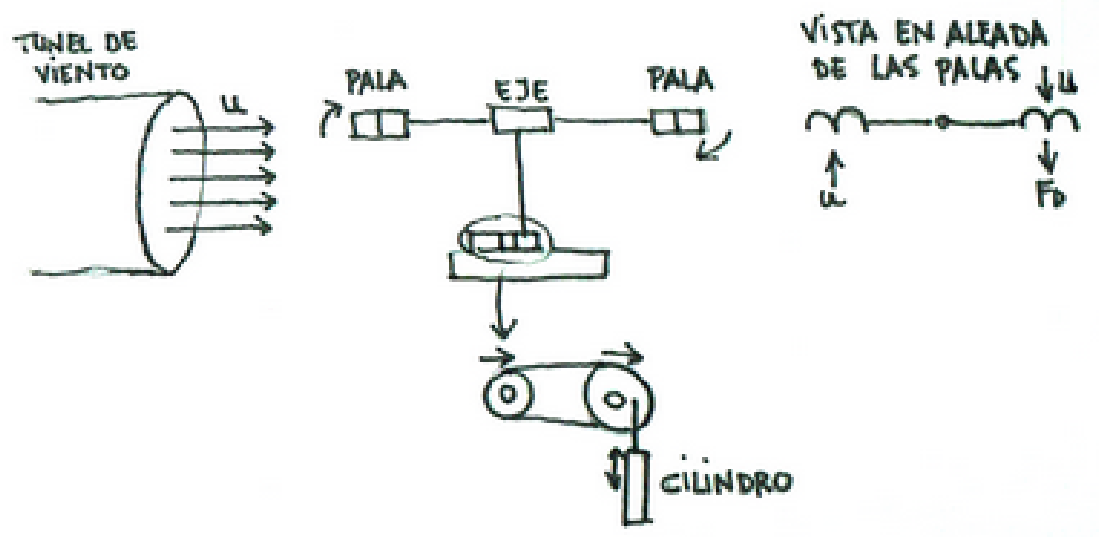

Figure 5. Sketch by a group of students using diagrammatic thinking to solve the problem.

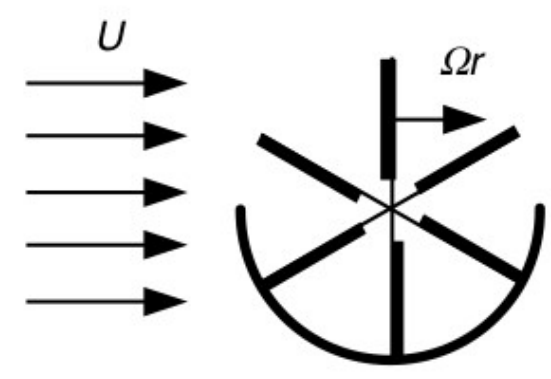

Drag machine

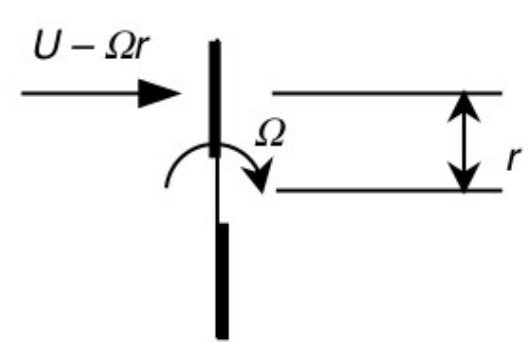

Drag machine model

Figure 6. Scheme of drag machine with plane blades protected by semicylinder, used as an analogical source [13].

- The combination of these heuristic tools in the group dialogue established deep reflective thinking, thus continuously generating and evaluating ideas.

- Therefore, the highly motivated group discussions towards the solution of this challenge, and reflecting on different types of solutions in each part of the problem, also implied a metacognitive 'learn to learn' exercise in the groups to establish a working plan for preparing the final report (see second phase in Figure 3).

- Generally, very good work atmosphere was observed in the groups.

- The students with a clear intuition of part of the solution helped others and taught the key elements of the issue. So, there was group heteroevaluation and criticism for successful learning for all (se third phase of learning strategy in Figure 3).

These qualitative facts were coherent with the quantitative results obtained for the items in the enquiries (see Table 3) and the learning strategies described in the Figure 3. The first item of the table is about the development of competencies, and its very good results showed that this kind of complex group problem-solving challenge develops, in the students' opinion, real competencies needed in future work life and transformative social action towards sustainability [46]. 


\section{Discussion}

Co-operation between heuristic tools, within the 'art of solving problems', is a well-known mental activity in modern studies on scientific creativity [4,40,47-50]. This modern approach criticises the classical Kuhnian view of the construction of new concepts based on cognitive persistence of paradigms, paradigm shifts triggered by anomalies, and the role of thought experiments in disconfirming theories [51]. Lakatos [52] was one of the first authors that criticized the strong and sudden changes in Kuhnian paradigms, and introduced a view based on step-by-step proofs, refutations, concept sketching, counterexamples, and informal moves for the gradual construction of a solution to a problem. Polya and others also defended and demonstrated this gradual view in different problem-solving examples in mathematics versus paradigmatic disruptions in classical theory [22,53].

Recent common criticisms of the classical theory of conceptual change say that it is incomplete because it does not consider the motivation, social learning ('learn to learn' co-operatively), or other metacognitive aspects that are present in these combinations of heuristic tools with analogies or diagrammatic thinking. Clement [4] (p. 107) underlined this anomaly and the search for a proper analogy as a source of motivation to solve a given problem because the associated tension with the dissatisfaction with their understanding apparently drives students to keep re-attacking the problem until they make a breakthrough.

In our case, the main anomaly was the counterdrag in the reverse side of the eight moving blades that was dominated not by relative velocity, but by absolute lineal velocity. The abstraction process to insert this important element into the final equation and the $\mathrm{R}$ code generated a deep discussion in the groups. In fact, abstraction is one of the key concepts of object-oriented programming languages such as R, which handles complexity by hiding unnecessary details. It allows to implement more complex logic on the basis of the abstraction process and the consequent development of computational thinking [54].

In the context of abstraction, anomalies, and the search for adequate analogical sources, we also observed that understanding dissatisfaction is increased if there are other students in the group that think that they understand the problem or part of it, and that it opens a rich group discussion towards understanding. This establishes successful group-learning self-evaluation for all, and continuously reflective thinking generating and evaluating ideas. Therefore, this co-operation accounted for the good group atmosphere that could be described as a 'learn to learn' environment with rich heteroevaluation proposed in the third phase of the learning strategies, shown in Figure 3.

Furthermore, Sustainable Development Goals (SDG, [55]) were present in this work [15]. Apart from advances in educational practices and their quality, mentioned before (SDG 4), the windpump activity iswasclearly contextualized in the fight against climate change (SDG 13), the development of clean-energy sources (SDG 7), and the access to clean water in developing countries (SDG 6).

Several studies in Africa and India showed the importance of the windpumps to obtain clean water from wells, and their positive effects on a community's health $[19,20,56]$. In the present case, the use of statistical wind distribution in a given location based on reanalysis or mesoscale models (extensively used by the authors $[3,10,35,38]$ ) could relate each wind-speed occurrence with corresponding water flow (Equation (4)); this method enabled more projects for our students to estimate the daily amount of pumped water. This daily water storage for different months or seasons is a key issue for sustainable development in developing countries, but not only there. There are regions like the Canary Islands (Spain) in which wind-powered hydrostorage systems contribute to increase the share of renewable energies with real achievements in the island of El Hierro [57-59].

In the students' opinion, this kind of complex challenge helps develop their competencies for future work life. This was to be expected, since the challenge was integrated in social and sustainable goals, and enabled reflective and creative thinking, and hard group work. Furthermore, this was not a guided problem-solving activity with a previously established axiom. On the contrary, students had to solve the problem from scratch, find relevant information, properly classify it, and generate new heuristic perspectives. 


\section{Conclusions}

The windpump group challenge activated reflective thinking via co-operation between different heuristic tools (analogical reasoning, diagrammatic thinking, and abstraction) in a highly motivated class atmosphere. Windpumping is also a renewable source of energy, so this educational challenge was fully integrated in the objectives of sustainable development within the Faculty of Engineering in Renewable Energies [1].

In the future, new versions of the windpump will be designed and fabricated to extend the complexity and the degree of freedom of the problem-solving activity. The form of the blades in the reverse side could be changed to adapt the counterdrag force. The number of blades and arms could also be changed, or the pumping height could be higher-lengthening the tube to the upper floor. Other kinds of drag machines could also be fabricated on the basis of simple working principles like the one in the Savonious turbine [20], since it was also developed in this laboratory for the integration of wind turbines in buildings [27].

Author Contributions: Conceptualization, methodology, software, investigation, writing-review and editing, supervision, project administration, and funding acquisition, A.U. and G.I.-B. All authors have read and agreed to the published version of the manuscript.

Funding: This work was funded by the Spanish Government's MINECO project CGL2016-76561-R (AEI/FEDER EU) and the University of the Basque Country (UPV/EHU funded project GIU17/02). It also had assistance from the ERAGIN educative program and the CAMPUS BIZIA LAB sustainability program of UPV/EHU. All calculations were carried out in the framework of R Core Team (2018) [43]. The authors would also like to thank former students Christian Arriola and Lukas Tapia for their invaluable help at manufacturing the windpump with brilliant laboratory technician Gorka Quintana.

Conflicts of Interest: The authors declare no conflict of interest

\section{Abbreviations}

The following abbreviations are used in this manuscript:

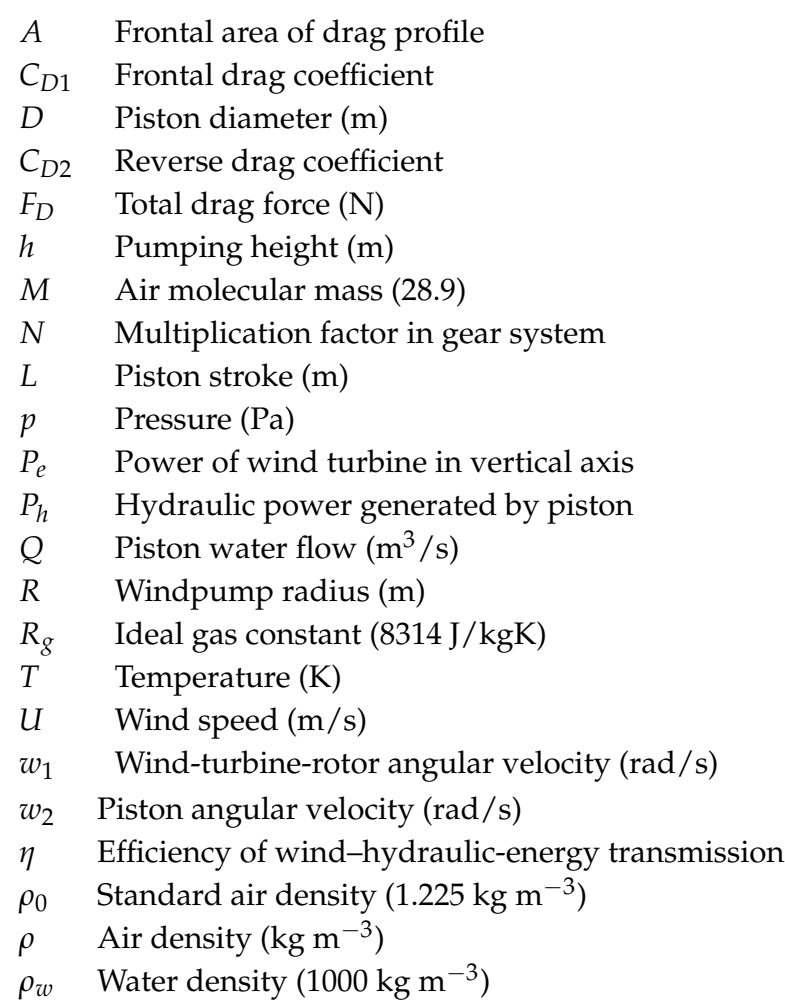




\section{References}

1. EIG-Eibar, Grade of Eng. in Renewable Energies. Available online: https://www.ehu.eus/es/web/eibar/ energia-berriztagarrien-ingeniaritzako-gradua (accessed on 15 January 2020).

2. Mitigation, C.C. Summary for Policymakers. In Proceedings of the IPCC Special Report on Renewable Energy Sources and Climate Change Mitigation, Abu Dhabi, UAE, 5-8 May 2011.

3. Ulazia, A.; Ibarra-Berastegi, G. Study of ocean and wind energy potential with R: An innovative experience in the classroom. In Proceedings of the 2nd International Conference on Higher Education Advances (HEAD'16), Valencia, Spain, 21-23 June 2016; Editorial Universitat Politècnica de València: Valencia, Spain, 2016; pp. 9-17.

4. Clement, J. Creative Model Construction in Scientists and Students: The Role of Imagery, Analogy, and Mental Simulation; Springer Science \& Business Media: Cham, Switzerland, 2008.

5. Chi, M.T.; Feltovich, P.J.; Glaser, R. Categorization and representation of physics problems by experts and novices. Cogn. Sci. 1981, 5, 121-152. [CrossRef]

6. Chi, M.T.; Bassok, M.; Lewis, M.W.; Reimann, P.; Glaser, R. Self-explanations: How students study and use examples in learning to solve problems. Cogn. Sci. 1989, 13, 145-182. [CrossRef]

7. Newell, A.; Simon, H.A. Human Problem Solving; Prentice-Hall: Englewood Cliffs, NJ, USA, 1972; Volume 104.

8. Manterola, A.U.; Berastegi, G.I. Itsas Energia irakasten Rrekin. In Ekaia; EHUko Zientzia eta Teknologia Aldizkaria: Leioa, Spain, 2015; pp. 1-13.

9. Ibarra-Berastegi, G.; Ganzedo, U.; Sanez, J.; Ezcurra, A.; Errasti, I.; Elias, A.; Barona, A.; Insausti, L. Linking high education and research using free software: Two experiences with R. In Proceedings of the WSEAS Transactions on Advances in Engineering Education, Athens, Greece, 29-31 December 2009; pp. 70-75.

10. Ulazia, A.; Urresti, A.; Antxustegi, M.; Gonzalez-Alriols, M.; Campos, A.; Ibarra-Berastegi, G. Using open software to teach resource assessment of solar thermal and geothermal energy. In Proceedings of the 3rd International Conference on Higher Education Advances, Valencia, Spain, 21-23 June 2017; Editorial Universitat Politècnica de València: Valencia, Spain, 2017; pp. 1381-1387.

11. Ibarra-Berastegi, G.; Garcia-Arriba, R. An educational example using free software in a industrial engineering master. DYNA 2017, 92, 606, doi:10.6036/8555. [CrossRef]

12. Ibarra-Berastegi, G.; Ulazia, A.I.U.; Carreño-Medinabeitia, S.C. Combining practicals at a research laboratory, visits to facilities and hands-on computer exercises to teach marine energy. In Proceedings of the ICERI2019 12th International Conference of Education, Research and Innovation, Seville, Spain, 12-13 November 2019; pp. 1327-1333.

13. Manwell, J.F.; McGowan, J.G.; Rogers, A.L. Wind Energy Explained: Theory, Design and Application; John Wiley \& Sons: Hoboken, NJ, USA, 2010.

14. EIG-Eibar, Renewable Energy Laboratories. Available online: https://www.ehu.eus/es/web/eibar/ laborategiak (accessed on 15 January 2020).

15. General United Nations Assembly. Sustainable Development goals. SDGs Transform. Our World 2015, 2020. https: / / sustainabledevelopment.un.org/?menu=1300 (accessed on 15 January 2020).

16. Lucas, A. Wind, Water, Work: Ancient and Medieval Milling Technology; Brill: Leiden, The Netherlands, 2006; Volume 8.

17. Ibarra-Berastegi, G.; Rodriguez, M.; Elias, A.; Caamaño, J. Las máquinas hidráulicas y de fluidos a lo largo de la historia. DYNA 1997, 72, 9-15. Available online: http:/ / www.revistadyna.com/Documentos / pdfs5C19975CMayo5C1770DYNAINDEX.pdf (accessed on 15 January 2020).

18. Omer, A.M. Solar water pumping clean water for Sudan rural areas. Renew. Energy 2001, 24, $245-258$. [CrossRef]

19. Rastogi, T. Windpump Handbook; Tata Energy Research Institute, Documentation Centre: Bombay, India, 1982.

20. Rabah, K.; Osawa, B. Design and field testing Savonius wind pump in East Africa. Int. J. Ambient Energy 1996, 17, 89-94. [CrossRef]

21. Popper, K. Karl Popper: Philosophy and Problems; Cambridge University Press: Cambridge, UK, 1995; Volume 39.

22. Polya, G. How to Solve It: A New Aspect of Mathematical Method; Number 246; Princeton University Press: Princeton, NJ, USA, 2004; Volume 39.

23. Hanson, N.R. The logic of discovery. J. Philos. 1958, 55, 1073-1089. [CrossRef] 
24. De Miguel Díaz, M.; Alfaro Rocher, I.; Apodaca Urquijo, P.; Arias Blanco, J.; García Jiménez, E.; Lobato Fraile, C.; Pérez Boullosa, A. Modalidades de Enseñanza Centradas en el Desarrollo de Competencias: Orientaciones para Promover el Cambio Metodológico en el Espacio Europeo de Educación superior; Servicio de Publicaciones; Universidad de Oviedo: Oviedo, Spain, 2005.

25. SAE-HELAZ, ERAGIN Program. Available online: https://www.ehu.eus/es/web/sae-helaz/eragin (accessed on 15 January 2020).

26. EHU's Campus Bizia Lab Sustainability Program. Available online: https://www.ehu.eus/es/web/ iraunkortasuna/campus-bizia-lab (accessed on 15 January 2020).

27. Garcia, O.; Ulazia, A.; del Rio, M.; Carreno-Madinabeitia, S.; Gonzalez-Arceo, A. An Energy Potential Estimation Methodology and Novel Prototype Design for Building-Integrated Wind Turbines. Energies 2019, 12, 2027. [CrossRef]

28. Clausen, P.; Wood, D. Recent advances in small wind turbine technology. Wind Eng. 2000, 24, $189-201$. [CrossRef]

29. Bhandari, B.; Lee, K.T.; Lee, C.S.; Song, C.K.; Maskey, R.K.; Ahn, S.H. A novel off-grid hybrid power system comprised of solar photovoltaic, wind, and hydro energy sources. Appl. Energy 2014, 133, 236-242. [CrossRef]

30. Maxon Motor. Available online: https://www.maxonmotor.com (accessed on 15 January 2020).

31. Alcalá, D.H.; Garijo, A.H.; Pérez-Pueyo, Á.; Fernández-Río, J. Cooperative Learning and Students' Motivation, Social Interactions and Attitudes: Perspectives from Two Different Educational Stages. Sustainability 2019, 11, 7005. [CrossRef]

32. Leigh, F. Platonic dialogue, maieutic method and critical thinking. J. Philos. Educ. 2007, 41, 309-323. [CrossRef]

33. Carvill, J. Mechanical Engineer's Data Handbook; Butterworth-Heinemann: Oxford, UK, 1994.

34. Flandro, G.A.; McMahon, H.M.; Roach, R.L. Basic Aerodynamics: Incompressible Flow; Cambridge University Press: Cambridge, UK, 2011; Volume 31.

35. Ulazia, A.; Ibarra-Berastegi, G.; Sáenz, J.; Carreno-Madinabeitia, S.; González-Rojí, S.J. Seasonal correction of offshore wind energy potential due to air density: Case of the Iberian Peninsula. Sustainability 2019, 11, 3648. [CrossRef]

36. Ulazia, A.; Sáenz, J.; Ibarra-Berastegi, G.; González-Rojí, S.J.; Carreno-Madinabeitia, S. Global estimations of wind energy potential considering seasonal air density changes. Energy 2019, 187, 115938. [CrossRef]

37. Ulazia, A.; Nafarrate, A.; Ibarra-Berastegi, G.; Sáenz, J.; Carreno-Madinabeitia, S. The Consequences of Air Density Variations over Northeastern Scotland for Offshore Wind Energy Potential. Energies 2019, 12, 2635. [CrossRef]

38. Ulazia, A.; Gonzalez-Rojí, S.J.; Ibarra-Berastegi, G.; Carreno-Madinabeitia, S.; Sáenz, J.; Nafarrate, A. Seasonal air density variations over the East of Scotland and the consequences for offshore wind energy. In Proceedings of the 7th International Conference on Renewable Energy Research and Applications (ICRERA), Paris, France, 14-17 October 2018; pp. 261-265.

39. Nickles, T. Scientific Discovery, Logic, and Rationality; Springer Science \& Business Media: Cham, Switzerland, 2012; Volume 56.

40. Ulazia, A. Multiple roles for analogies in the genesis of fluid mechanics: How analogies can cooperate with other heuristic strategies. Found. Sci. 2016, 21, 543-565. [CrossRef]

41. Kordig, C.R. Discovery and justification. Philos. Sci. 1978, 45, 110-117. [CrossRef]

42. Tejedor, G.; Segalàs, J.; Barrón, Á.; Fernández-Morilla, M.; Fuertes, M.T.; Ruiz-Morales, J.; Gutiérrez, I.; García-González, E.; Aramburuzabala, P.; Hernández, À. Didactic strategies to promote competencies in sustainability. Sustainability 2019, 11, 2086. [CrossRef]

43. R-cran, The Comprehensive R Archive Network. Available online: https://cran.r-project.org/ (accessed on 15 January 2020).

44. Crawley, M.J. The R Book; John Wiley \& Sons: Hoboken, NJ, USA, 2012.

45. Verzani, J. Using R for Introductory Statistics; Chapman and Hall/CRC: London, UK, 2018.

46. Frisk, E.; Larson, K.L. Educating for sustainability: Competencies \& practices for transformative action. J. Sustain. Educ. 2011, 2, 1-20. 
47. Ulazia, A. Activation of the Eddy Mental Schema, Multiple Analogies and Their Heuristic Cooperation in the Historical Development of Fluid Dynamics. In Building Theories; Springer: Cham, Switzerland, 2018; pp. 145-166.

48. Danks, D.; Ippoliti, E. Building Theories: Heuristics and Hypotheses in Sciences; Springer: Cham, Switzerland, 2018; Volume 41.

49. Clement, J. Using bridging analogies and anchoring intuitions to deal with students' preconceptions in physics. J. Res. Sci. Teach. 1993, 30, 1241-1257. [CrossRef]

50. Clement, J. Observed methods for generating analogies in scientific problem solving. Cogn. Sci. 1988, 12, 563-586. [CrossRef]

51. Kuhn, T.S. The Structure of Scientific Revolutions; Chicago University Press: Chicago, IL, USA, 1962.

52. Lakatos, I. Proofs and Refutations: The Logic of Mathematical Discovery; Cambridge University Press: Cambridge, UK, 2015.

53. Cellucci, C. Is mathematics problem solving or theorem proving? Found. Sci. 2017, 22, 183-199. [CrossRef]

54. Romero, M.; Lepage, A.; Lille, B. Computational thinking development through creative programming in higher education. Int. J. Educ. Technol. High. Educ. 2017, 14, 42. [CrossRef]

55. United Nations. Sustainable Development Goals. Available online: https://www.un.org/ sustainabledevelopment/ (accessed on 15 January 2020).

56. Harries, M. Disseminating wind pumps in rural Kenya-Meeting rural water needs using locally manufactured wind pumps. Energy Policy 2002, 30, 1087-1094. [CrossRef]

57. Bueno, C.; Carta, J.A. Wind powered pumped hydro storage systems, a means of increasing the penetration of renewable energy in the Canary Islands. Renew. Sustain. Energy Rev. 2006, 10, 312-340. [CrossRef]

58. Godina, R.; Rodrigues, E.; Matias, J.; Catalão, J. Sustainable energy system of El Hierro island. In Proceedings of the International Conference on Renewable Energies and Power Quality (ICREPQ'15), Renewable Energy and Power Quality Journal (RE\&PQJ), La Coruna, Spain, 25-27 March 2015; Volume 13, pp. 46-51.

59. Bueno, C.; Carta, J. Technical-economic analysis of wind-powered pumped hydrostorage systems. Part II: Model application to the island of El Hierro. Sol. Energy 2005, 78, 396-405. [CrossRef] 